\title{
Análise da cobertura de sites jornalísticos da América do Sul, Europa e Ásia sobre os povos indígenas atingidos pela UHE Belo Monte
}

Analysis of South American, European and Asian online news media coverage of indigenous peoples affected by the Belo Monte dam

Análisis de cobertura de los sitios periodísticos de América del Sur, Europa y Asia sobre los pueblos indígenas afectados por la hidroeléctrica Belo Monte

DOI: https://doi.org/10.1590/1809-5844202115

\section{Renata da Cruz Paes ${ }^{1}$}

http://orcid.org/0000-0002-1230-2490

\section{Priscila Sanjuan de Medeiros Sarmento ${ }^{2}$}

https://orcid.org/0000-0002-5001-9573

\author{
Altem Nascimento Pontes ${ }^{1}$ \\ https://orcid.org/0000-0002-9001-4603
}

${ }^{1}$ (Universidade do Estado do Pará, Centro de Ciências Naturais e Tecnologia, Programa de Pós-Graduação em Ciências Ambientais. Belém - PA, Brasil).

${ }^{2}$ (Instituto Tecnológico Vale Desenvolvimento Sustentável. Belém - PA, Brasil).

\section{Resumo}

Ao surgirem as primeiras repercussões da construção da Usina Hidrelétrica (UHE) Belo Monte, os povos indígenas se manifestaram continuamente contra o empreendimento. A imprensa acompanhou tanto o andamento das obras da Usina quanto as manifestações dos povos indígenas brasileiros em recusa à Usina. Diante disso, a pesquisa almeja investigar a visibilidade e representação desses povos em sites jornalísticos de maior circulação no Brasil e em outros 12 países estrangeiros. A amostragem se constitui de 54 matérias jornalísticas, publicadas entre 2005 a 2017. Por meio da Análise de Conteúdo (AC) de Bardin (1977), os resultados revelaram que os povos indígenas são descritos pelos jornais como "invasores" e "de menor capacidade”. Os jornais estrangeiros deram mais abertura a fala dos povos indígenas contra a UHE Belo Monte, do que os jornais brasileiros, que priorizaram o discurso do governo e dos interesses políticos.

Palavras-chave: Representações sociais. Amazônia brasileira. Análise de Conteúdo. Belo Monte. Povos indígenas. 


\begin{abstract}
With the first repercussions of the construction of the Belo Monte hydroelectric dam, indigenous peoples started a continuous claim making against the project. The press gave attention to both the progress of the plant's construction and the manifestations of the Brazilian indigenous peoples in refusal of the plant. This research aimed to investigate the visibility and representation of these peoples on news websites of greater circulation in Brazil and 12 other countries. The sample consisted of 54 newspaper articles published between 2005 and 2017. Data were analyzed through Bardin's Content Analysis (1977) and the results revealed that indigenous peoples are described as "invaders" and "less able" in the newspapers. Foreign newspapers gave more voice to indigenous peoples, for them to express their stance against the Belo Monte dam project, than Brazilian newspapers, while the latter prioritized the government's discourse and political interests.
\end{abstract}

Keywords: Social representations. Brazilian Amazon. Content analysis. Belo Monte. Indigenous peoples.

\title{
Resumen
}

Cuando aparecieron las primeras repercusiones de la construcción de la Central Hidroeléctrica (UHE) de Belo Monte, los pueblos indígenas se manifestaron continuamente en contra de la empresa. La prensa siguió tanto el avance de las obras de la Planta como las manifestaciones de los pueblos indígenas brasileños en el rechazo de la Planta. A la luz de esto, la investigación tiene como objetivo investigar la visibilidad y representación de estos pueblos en los sitios periodísticos de mayor circulación en Brasil y en otros 12 países extranjeros. La muestra consta de 54 artículos periodísticos, publicados entre 2005 y 2017. A través de Content Analysis (CA) de Bardin (1977), los resultados revelaron que los pueblos indígenas son descritos por los periódicos como "invasores” y “de menor capacidad”. Los periódicos extranjeros dieron un discurso más abierto a los pueblos indígenas contra el HPP Belo Monte, que los periódicos brasileños, que dieron prioridad al discurso del gobierno y los intereses políticos.

Palabras clave: Representaciones sociales. Amazonia brasileña. Análisis de contenido. Belo Monte. Pueblos indigenas.

\section{Introdução}

De acordo com o último censo realizado pelo Instituto Brasileiro de Geografia e Estatística (IBGE, 2010), a população indígena no Brasil é de aproximadamente 817 mil. Ainda segundo o mesmo censo, ela está em 63,8\% das áreas rurais, 36,2\% das áreas urbanas, distribuída em 698 terras demarcadas, sendo 470 regularizadas e reconhecidas pelo Estado (RICARDO et al., 2015). Muito mais do que locais para estabelecer moradia, as Terras Indígenas (TI) "representam a manutenção das tradições e identidades dos povos que nelas vivem” (DOURADO et al., 2017, p. 231).

Antes da chegada dos colonizadores, pouco mais de 1.500 anos atrás, a Amazônia já era ocupada pelos povos indígenas (LIMA-FILHO, 2015). Em meio à biodiversidade da região, esses povos continuam a construir um estilo de vida e tradições baseadas no uso 
dos recursos naturais para atender às necessidades de alimentação, saúde e socialização (SCHWARTZMAN et al., 2013). Enquanto isso, nas grandes metrópoles, há o "rápido crescimento da demanda global por novas fontes de energia e à diminuição de locais, no planeta, com potencialidades para tanto” (FRANCO; FEITOSA, 2013, p. 94).

Lima-Filho (2015) lembra que, no passado, para retornarem as próprias terras, os povos indígenas agiam com a força da flecha contra os colonizadores, porém, na atualidade, a resistência é sobre os madeireiros, garimpeiros e os perigosos barrageiros. As invasões por parte dos grandes projetos hidrelétricos se tornaram latentes ameaças aos povos (CARNEIRO FILHO; SOUZA, 2009, VERDUM, 2012).

Nesse sentido tem-se o caso barragem projetada para ser a terceira maior do mundo, a Usina Hidrelétrica (UHE) Belo Monte, que ocupa parcialmente as áreas da T.I. Paquiçamba e da T.I. Arara da Volta Grande, no município de Vitória do Xingu, microrregião de Altamira, no estado do Pará (BERMANN, 2012).

Segundo Stropper (2014), a área em que se situa a hidrelétrica é rica em fauna e flora, sendo povoada também por ribeirinhos, agricultores e pescadores. No entanto, raramente esses atores são consultados sobre as decisões tomadas a respeito das terras em que habitam (SANTOS et al., 2012).

\section{Imprensa, povos indígenas e Belo Monte}

Na década de 1970, os povos indígenas já se manifestavam ao não favorecimento da Usina de Belo Monte, naquela época denominado de Usina Kararaô, nome alusivo ao grito indígena dos Kayapó (FEARNSIDE, 2015). Nesse período, iniciaram-se os Estudos de Inventário Hidrelétrico da Bacia Hidrográfica do Rio Xingu, publicados no Plano Nacional de Energia Elétrica (BRASIL) 1987/2010. Esse estudo, apoiado pelo governo de José Sarney, frisou que "o aproveitamento do Rio Xingu se constituirá, possivelmente, no maior projeto nacional no final deste século e começo do próximo” (BRASIL, 1987).

Em 1989, foi sediado, em Altamira (PA), o Encontro dos Povos Indígenas do Xingu. Esse encontro reuniu o "diretor e posterior presidente da Eletronorte, Antônio Muniz Lopes, assim como o presidente do Instituto Brasileiro do Meio Ambiente dos Recursos Naturais Renováveis (Ibama), o prefeito de Altamira, ambientalistas, povos indígenas e o cantor inglês Sting” (FLEURY; ALMEIDA, 2013, p. 143).

Na ocasião, diante da imprensa nacional e internacional, a índia Tuíra apontou o facão para o rosto do presidente da Eletronorte. A imagem repercutiu o mundo e, devido a repercussão midiática em relação à Usina e de pressões de ambientalistas, o projeto de construção adormeceu por um período.

“Anos depois, José Antônio Muniz Lopes retomou o projeto de barramento do rio Xingu” (ALONSO, 2015, p. 83). Mas, ele não esteve sozinho. Com o apoio do governo Lula e do Programa de Aceleração do Crescimento (PAC), foram criados condições e incentivos para a construção da hidrelétrica. 
Segundo Montaño (2014), Lula solicitou ao ministro do Meio Ambiente, em 2009, Carlos Minc, para simplificar o processo de licenciamento ambiental e, assim, agilizar o andamento do PAC e dos investimentos de Belo Monte.

Lula também teve o suporte de Dilma, que antes de assumir a presidência, era exministra do Ministério de Minas e Energia (MME) e ex-chefe da Casa Civil. Fainguelernt (2016) lembra que em 2004, devido a inúmeras irregularidades apontadas pelo Ministério Público Federal (MPF), o licenciamento ambiental de Belo Monte foi paralisado. "Mesmo assim, um ano depois (2005), o MME, através de sua então ministra Dilma Rousseff, oficializou ao MMA e à Funai que Belo Monte seria considerada prioridade estratégica de governo” (FUNAI, 2009, p. 12).

Posteriormente, ao assumir a presidência, Dilma garantiu, conforme Fisher (2014), preços mais baixos para a energia elétrica, com a esperança de atrair mais investidores para Belo Monte. Em meio a dezenas de protestos de ambientalistas, movimentos sociais e dos próprios povos indígenas, em 5 de maio de 2016, Dilma Rousseff, presidente do Brasil na época, inaugurou a UHE Belo Monte, com capacidade instalada de 11.233,1 Megawatts (MW) (BRASIL, 2016). Mesmo com mobilizações sociais e ambientais, “o Projeto da Barragem foi imune a todos os argumentos - lógicos, jurídicos e morais - e bem-sucedido na obtenção de suporte nas agências governamentais que o promoveram, nos bancos que o financiaram e nas empresas que investiram nele” (FEARNSIDE, 2018, p. 164).

Em 2010, o vencedor do leilão de licitação das obras da UHE Belo Monte foi o consórcio Norte Energia S/A (Nesa), composto por empresas estatais como a Eletrobrás, Chesf e Eletronorte; empresas privadas como Vale e J. Malucelli Energia e outros potentes investidores (OLIVEIRA; MARQUES, 2012). O Banco Nacional do Desenvolvimento (BNDES) concedeu empréstimo de R\$ 30 bilhões para a construção da usina (FAINGUELERNT, 2016).

O dinheiro do BNDES tratava-se de recursos públicos (OLIVEIRA, MARQUES; 2012). Com esses recursos, a hidrelétrica no Xingu ganhou forma e o "número de atingidos pelas obras da UHE Belo Monte e suas consequências chegaram a 40 mil pessoas e a 24 etnias que habitavam a bacia do Xingu” (SUDATTI, 2014, p. 15).

O projeto também ganhou apoio em forma de discurso. Pesquisadores influentes, como o diretor da coordenação dos programas de Pós-Graduação em Engenharia da Universidade Federal do Rio de Janeiro (UFRJ), Luiz Pinguelli Rosa, dissera em entrevista que impactos socioambientais como o de Belo Monte sempre existirão, porém, há necessidade de desenvolvimento do país com suprimento energético (OLIVEIRA, 2010). Ao expor opiniões de pessoas influentes na mídia, "o Brasil foi disfarçando a grande opressão que sofre a população indígena ao longo dos anos” (BAPTISTA; RODRIGUES; LOPES, 2016, p. 155).

Lula e Dilma, além de reforçarem o discurso pró-barragem na Amazônia, realizaram manobras para que o projeto fosse aprovado a todo custo. "Isenções fiscais, facilidades para aquisição de crédito. Concomitantemente houve o ataque e inevitável enfraquecimento de Órgãos e instituições públicas responsáveis pelo acompanhamento e avaliação dos estudos de viabilidade técnica deste empreendimento” (FEIO et al., 2020, p. 44-45). 
Diante do potencial que a mídia tem de expor opiniões e os envolvidos em assuntos de interesse mundial, a presente pesquisa almeja investigar a visibilidade e representação desses povos pelos sites jornalísticos de maior circulação no Brasil e em outros 12 países estrangeiros. Questiona-se o papel que os veículos jornalísticos têm em dar voz aos povos indígenas, investigando-se a atuação da mídia como fonte de informação para o mundo sobre os impactos socioambientais da UHE Belo Monte.

\section{Metodologia}

A pesquisa foi realizada por meio da Análise de Conteúdo (AC), de acordo com os teóricos Bardin (1977), Chizzotti (2010), Silva et al. (2005) e Caregnato e Mutti (2006). A Análise de Conteúdo é "um conjunto de técnicas das comunicações, visando obter por procedimentos sistemáticos e objetivos de descrição do conteúdo das mensagens indicadores, que permitem a inferência de conhecimentos relativos às condições de recepção/produção” (BARDIN, 1977, p. 48).

Chizzotti (2010, p. 114) pontua que a AC é como “um tipo de análise da comunicação que pretende garantir a imparcialidade objetiva, socorrendo-se da quantificação das unidades do texto claramente definidas, para gerar resultados quantificáveis ou estabelecer a frequência estatística das unidades de significado”.

A AC é uma técnica de investigação utilizada tanto para pesquisas quantitativas quanto qualitativas. A diferença é que, segundo Silva et al. (2005) e Caregnato e Mutti (2006), a quantitativa resulta numa frequência de características repetidas no conteúdo do texto, enquanto a qualitativa se verifica a ausência ou presença de determinada característica de um trecho da mensagem.

A Análise de Conteúdo se apresenta como "um transporte de significações de um emissor para um receptor controlado ou não por este, deveria poder ser escrito, decifrado pelas técnicas de análise de conteúdo” (BARDIN, 1977, p. 32).

Neste trabalho, utilizou-se três procedimentos para a construção da análise de conteúdo das matérias jornalísticas: a pré-análise, categorização e tratamento dos dados. A pré-análise se constituiu da escolha dos veículos de comunicação jornalísticos de maior circulação no mundo, selecionados a partir do ranking dos maiores jornais do mundo, produzido pela Associação Nacional de Jornal (ANJ, 2010). A escolha dos sites baseou-se, ainda, nos autores Zago e Bastos (2013), que atualizaram os veículos de maior circulação no mundo, a partir de especialistas em pesquisas e auditorias de mídias nacionais e internacionais.

A partir dos jornais selecionados, identificaram-se os de maior impacto/circulação nos países do continente americano: Estados Unidos, Argentina, Brasil e Colômbia; do europeu: Alemanha, Espanha, França, Portugal, Reino Unido; e asiático: China, Coréia do Sul e Índia.

Para a escolha dos países de cada continente, priorizaram-se os mais populosos, de ligação histórica com o Brasil ou em que a imprensa estrangeira alcança o público brasileiro. Para cada país, dois jornais online foram selecionados, totalizando 24 páginas na internet. 
Dentre os 24 sites jornalísticos selecionados fez-se uma primeira amostragem de matérias jornalísticas sobre a UHE Belo Monte. A amostragem foi delimitada a partir do ícone de busca dos sites, no idioma original dos países, para que o próprio website do jornal fizesse o apanhado geral de conteúdo. As palavras-chave utilizadas foram: "Hidrelétrica Belo Monte" e "Belo Monte".

Em seguida, foram selecionadas apenas matérias que tratavam da temática dos povos indígenas. Em uma terceira triagem, identificaram-se as palavras empregadas pelos jornalistas para se referir aos povos indígenas. Foram elas: "Índio", "Povos Indígenas", "Guardiões", "Povos Amazônicos", “Indígenas”, "Protestantes”, "Etnias”, “Grupos”, "Homem”, "Famílias”, “Ambientalistas”, "Manifestantes” e "Brasileiros”. O levantamento das matérias jornalísticas ocorreu em publicações de 2005 a 2017. O período de 12 anos se justifica pelo fato de que, em 2005, o Congresso Nacional aprovou o processo de licenciamento da hidrelétrica (BRASIL, 2005), mesmo em meio aos protestos dos povos indígenas. Já 2017 foi escolhido por ter sido de início da presente pesquisa. A amostragem ainda se limitou a notícias e reportagens, do gênero jornalístico informativo (MARQUES DE MELO, 2010). Tavares (1997) define notícia como fatos de interesse imediato, ao contrário da reportagem, que aborda com maior profundidade um assunto, analisando-o e interpretando-o.

A categorização dos dados se deu pela leitura de cada matéria jornalística. Estabelecendo-se então as seguintes categorias:

- Termos frequentes: palavras mais utilizadas nos títulos das matérias para referirse aos povos indígenas;

- Autores: quem assina os conteúdos;

- Editoria: sessões temáticas em que o conteúdo está publicado;

- Local de autoria: em quais países/estados as matérias foram produzidas, visto que o local interfere na apuração da informação e a visão do jornalista sobre o fato;

- Tipos de fontes: a credibilidade do jornalista se baseia na relação fonte, jornalista e veículos (BERGER, 2003), de acordo com a classificação das fontes de Schmitz (2011);

- Aspectos positivos e negativos: pontos destacados nas matérias sobre os benefícios e malefícios causados por Belo Monte.

\section{Resultados e Discussão}

De janeiro de 2005 a dezembro de 2017, identificaram-se 1.188 matérias jornalísticas sobre a usina Belo Monte, sendo 245 internacionais e 943 nacionais. No entanto, apenas 54 matérias trataram sobre os povos indígenas, sendo 49 notícias e cinco reportagens. 
Em 12 anos de publicações sobre Belo Monte, apenas 4,6\% das 1.188 matérias colocam o indígena em pauta. Uma porcentagem mínima comparada a proporção de matérias sobre a usina.

A invisibilidade do povo indígena na imprensa indica o reflexo da supressão histórico. A Revista Tempo publicou, em 2007, um dossiê sobre povos indígenas, escrito pela historiadora Maria Regina Celestino. Ela questionou “onde estão os índios na História do Brasil?” (ALMEIDA, 2007, p. 1). Ao estudar a história indígena, Monteiro (1995, p. 221) concluiu que “para os índios, não há história, há apenas etnografia”.

Outra diferença notória foi entre a quantidade de notícias factuais e reportagens. A disparidade de publicações de uma para outra é um possível indicativo das mudanças no comportamento das produções das matérias jornalísticas.

As 54 matérias levantadas sobre os povos indígenas e a UHE Belo Monte foram publicadas em 15 sites jornalísticos. São eles: El Espectador e El Tiempo (Colômbia); El Mundo e El País (Espanha); Folha de S.Paulo e O Globo (Brasil); Jornal de Notícias (Portugal); La Nacíon (Argentina); Le Figaro e Le Monde (França); People’s Daily (China); Süddeutsche Zeitung (Alemanha); The Guardian e The Sunday Times (Reino Unido); e The New York Times (Estados Unidos).

Na primeira amostragem de 1.188 matérias, houve três vezes mais conteúdo publicado nos sites nacionais que internacionais. Todavia, ao se limitar à segunda amostragem de 54 publicações sobre Belo Monte e os povos indígenas, a imprensa internacional apresentou maior ocorrência de matérias, ao produzir mais que o dobro de conteúdo que a nacional. Foram 38 produções estrangeiras e 16 nacionais.

O resultado corrobora com que Nunes (2015, p. 270) ressalta a respeito dos temas diretamente ligados a região amazônica e que despertam interesse internacional "pela possibilidade de a região abrigar excedentes populacionais de outras partes do mundo, ser produtora de alimentos; e território com grandes reservas de recursos estratégicos (água, petróleo, gás, ferro, manganês, bauxita, urânio, biodiversidade)”.

\section{Termos frequentes}

A partir da leitura dos títulos das matérias internacionais e nacionais, identificouse 12 termos que fazem referência aos povos indígenas. A Figura 1 mostra que, em maior quantidade, os povos indígenas são chamados de “índios”, seguido de “indígenas” e em terceiro de "tribo". 
Figura 1 - Termos utilizados pelos jornais para se referir aos povos indígenas

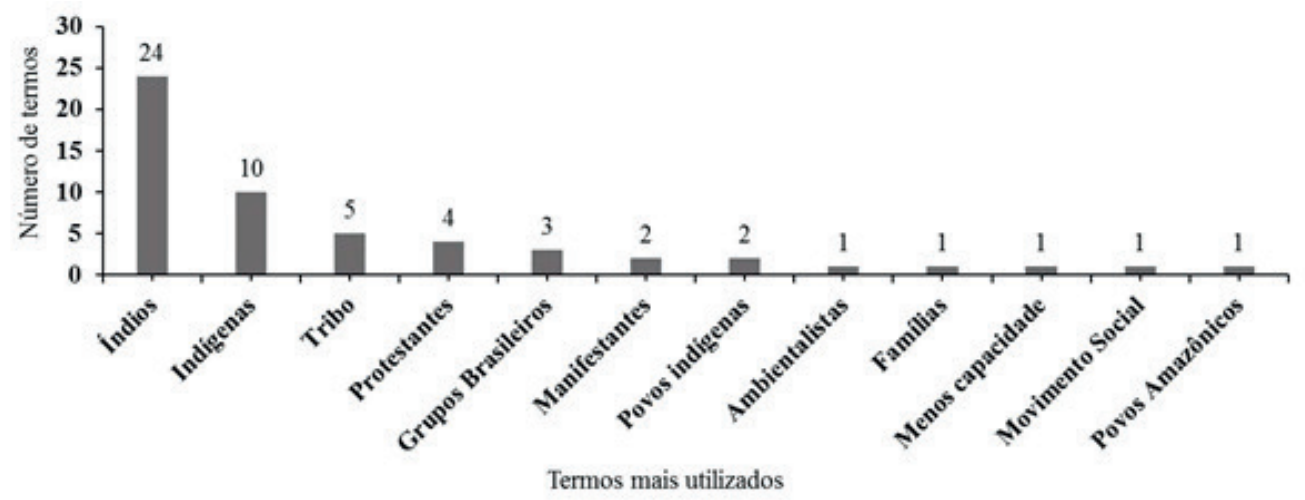

Fonte: pesquisa de campo, 2018.

Os autores Grupioni, Vidal e Fischmann (2001) enfatizam que é frequente ler ou ouvir na imprensa o nome "tribo" trocado, grafado ou pronunciado de maneira aleatória para se referir aos povos indígenas. Os mesmos autores ressaltam que esse comportamento da imprensa os reduz nas redações dos jornais "a um conjunto de pastas de recortes e fotografias classificadas genericamente como “índios”” (p. 65).

Collet, Paladino e Russo (2014) reforçam que o mais correto é usar a palavra "etnia” ou “povo indígena” para referir-se a esses povos, pois o conceito de “índio” está equivocado".

Outro termo que chamou atenção, embora não tenha sido o mais frequente, está na reportagem publicada em 11 de outubro de 2017, no jornal El País, com o seguinte título: "Eu luto por aqueles que têm menos capacidade de se defender”. O título está entre aspas, pois faz referência a fala da ambientalista e fundadora do movimento Xingu Vivo Para Sempre, Antonia Melo da Silva².

Antonia é filha de camponeses e, desde a década de 1980, passou a lutar pelas causas indígenas e contra Belo Monte. A matéria foca no papel de Antonia na defesa dos povos indígenas e, secundariamente, nos povos indígenas que foram deslocadas das suas moradias por conta da Usina.

Antonia é descrita pela autora do texto como alguém que está "na linha de frente de uma batalha”. A autora também atribui, a ambientalista, características como "tenacidade e coragem” e a chama de "guerreira da Amazônia”, qualidades de alguém que está à postos para defender um grupo de vulneráveis, nesse caso, os povos indígenas.

1 O conceito de “índio" surgiu quando os europeus chegaram à América e acreditaram estar na Índia e que a expressão "indígenas” foi trazida pelo colonizador, pois antes da chegada dos europeus, não havia uma palavra utilizada pela população nativa para se designar como coletivo.

2 Na reportagem, Antonia é entrevistada por ter sido vencedora de um prêmio sobre justiça social, lutar por mais de duas décadas contra a barragem Belo Monte, assim como defender os povos indígenas de Belo Monte. Disponível em: https://elpais.com/elpais/2017/10/09/ planeta_futuro/1507550012_733072.html. Acesso em: 9 set. 2018. 
Uma das falas de Antonia é relatada na reportagem. "Sei que estou fazendo a coisa certa; luto em defesa de quem menos pode de se defender, pelos direitos humanos, pela vida. É um compromisso que está dentro de mim e que me move a não desistir”.

Ao ressaltar que os povos indígenas são aqueles que “menos podem se defender”, retirase a autonomia e representatividade deles, que sabem lutar, de forma organizada. Danner (2018) enfatiza que as sociedades indígenas unem a transmissão dos saberes tradicionais com as tecnologias presentes para lutar contra a segregação, direito a demarcação de terrar, à saúde, escolas e crenças.

Lima e Gadelha (2015, p. 83) reforçam que "esse processo de inferiorização e subjugação do ‘povo tradicional amazônico’ continuou mesmo após a independência do Brasil, não mais numa perspectiva apenas internacional, mas também nacional”.

De acordo com Loureiro (2002), isso se explica pelo fato de que os grandes centros urbanos passaram a ser modelos de cultura formal e as populações urbanas da Amazônia, almejando parecer com o “desenvolvimento”, abandonaram os costumes da cultura indígena e passaram a vê-la de maneira pejorativa e estática.

Em pesquisa sobre “A desumanização presente nos estereótipos de índios e ciganos”, Lima, Faro e Santos (2016) analisaram as crenças pessoais e coletivas de 378 pessoas sobre a imagem dos povos indígenas e constataram: 19,6\% dos entrevistados acreditam que os povos indígenas são discriminados/excluídos; 11,1\% selvagens; 10,6\% aproveitadores/preguiçosos; 6,9\% diferentes; e 6,6\% inferiores/incapazes/ignorantes.

\section{Autores}

Quanto aos responsáveis pela apuração jornalística e escrita das matérias, a Figura 2 dividiu os autores dos conteúdos em três categorias: "agência” (matérias produzidas por agências de notícias e adquiridas pelos jornais apenas para reprodução), “jornalista” (matérias produzidas pelos repórteres do próprio veículo); e “não informado” (não especifica quem a produziu).

Figura 2 - Autores das matérias jornalísticas

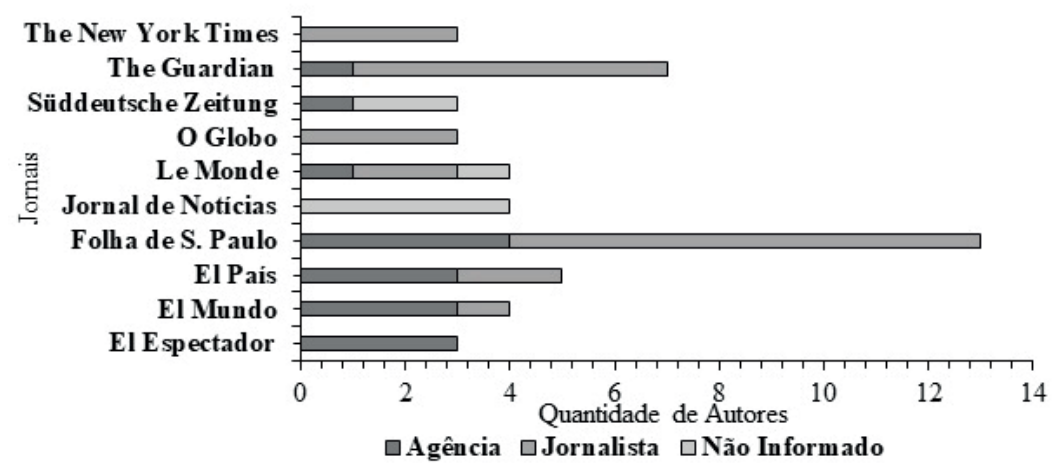

Fonte: pesquisa de campo, 2018. 
Embora a maioria das matérias tenha sido assinada pelos jornalistas dos veículos da grande imprensa (26), 16 foram de agências de comunicação. As agências noticiosas se transformaram em grandes meios de comunicação, com correspondentes e cobertura que a imprensa hegemônica, em muitos casos, não consegue abranger, por isso necessitam comprar informação.

Para Marques (2005, p. 40), as matérias das agências não chegam nas redações de forma bruta. Elas são apuradas, escritas e entregues prontas para os jornais. Ele ainda destaca que esses conteúdos "são imprescindíveis para os jornais por motivo econômico, mas em contrapartida acabam por gerar a homogeneização da notícia no conjunto das publicações”.

Vale ressaltar que as matérias de agências alimentam a mídia, nacional ou estrangeira, pública ou corporativa. Ou seja, um mesmo produto para uma série de veículos. Por conseguinte, multiplicam nos jornais um único discurso. Conforme Aguiar (2016, p.37), as agências "têm o potencial multiplicador de conteúdo, disseminando informações e discursos que podem obedecer ao planejamento para o desenvolvimento".

Das 13 publicações, quatro da Folha de S.Paulo foram de agências, uma da Reuters, maior agência internacional de notícias, com sede em Londres, e três da Agência Espanhola de Notícias (EFE). Em seguida, ficou o The Guardian com sete publicações, sendo seis por jornalistas e apenas uma de agência. O Globo não optou por notícias de agências ao publicar três matérias assinadas por jornalistas. Ao contrário do El Espectador que publicou apenas de agências.

Assis (2017, p. 48) considera os conteúdos de agências, informações de "segunda mão", pois são coletados, em geral, por telefone ou via internet. Para o mesmo autor, um bom trabalho jornalístico é capaz de dar ênfase aos personagens e ao ambiente com histórias completas e não fragmentadas, e isso "não se faz pelo telefone ou pelo e-mail. Não se faz às pressas”.

\section{Editoria}

Nos jornais ocorre a divisão por editorias temáticas, que são seções em que se agrupam assuntos comuns. A Figura 3 busca identificar em quais temáticas centrais as matérias sobre a UHE Belo Monte e os povos indígenas foram colocadas. 
Figura 3 - Editorias das matérias jornalísticas

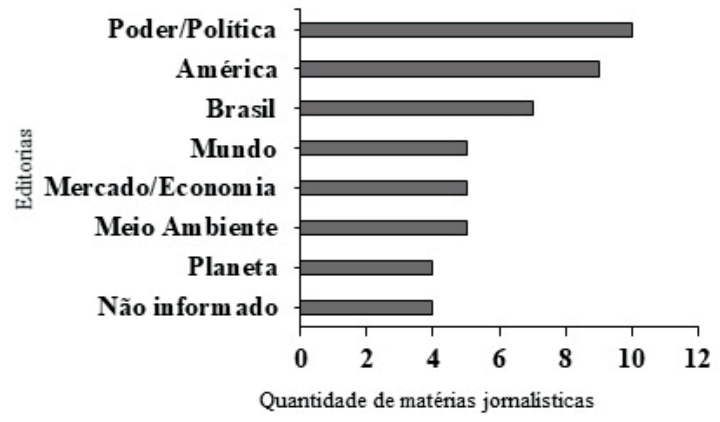

Fonte: pesquisa de campo, 2018.

A editoria “Poder/Política” apresentou o maior número de publicações (10), sendo sete da Folha de S.Paulo e três no Süddeutsche Zeitung. Em seguida ficou a editoria "América”, dos jornais People's Daily, El Mundo, The New York Times, El Espectador e The Guardian, que somadas dão nove publicações.

Foram cinco matérias classificadas dentro da editoria de "Meio Ambiente", publicadas na Folha de S. Paulo (2), The Guardian (2) e El Espectador (1). Elas têm o mesmo número da editoria de “Mercado", em alguns jornais identificada também como editoria de “Economia”. Apenas dois jornais brasileiros aparecem na editoria de Economia e Mercado, a Folha de S.Paulo (3) e O Globo (2).

Seligman e Furtado (2011, p. 402-403) justificam que a editoria de Política recebeu mais publicações e a temática também apareceu em Economia por "ser considerado tema fundamental de um jornal”. Portanto, segundo os mesmos autores, matérias nestas editorias não se destinam ao público popular e, sim, aos mais cultos, com linguagem apropriada à classe A e B, conhecida como formadora de opiniões.

Outro autor reforça esse pensamento. “Orientados para a elite, estes jornais compensam a baixa penetração nas camadas populares com a grande capacidade de produzir agendas, formatar questões e influenciar percepções e comportamentos (...)” (AZEVEDO, 2006, p. 95).

Os dados ainda revelam que a luta dos povos indígenas contra a construção da UHE Belo Monte recebeu baixa visibilidade nas editorias voltadas às temáticas ambientais e sociais. Visto que a UHE Belo Monte envolve questões socioambientais, Teixeira (2014) reforça que, diferente da editoria de "Meio Ambiente", as editorias de "economia, política, esporte e cultura já estão internalizadas na pauta da sociedade, e estão bem abastecidas de jornalistas para produzir informações sobre os respectivos temas. O meio ambiente não recebe a mesma importância e o mesmo tratamento dado às editorias supracitadas”. 
É fato que o jornalismo ambiental é interdisciplinar e não atua de forma isolada. Rocha (2018) afirma que o jornalismo ambiental está presente em campos econômicos, políticos, biológicos, sociológicos e culturais. Apesar disso, não se pode desconsiderar a abordagem didática, que esclarece a pauta do meio ambiente a um público não especializado.

\section{Local de autoria}

A Figura 4 apresenta os locais em que as matérias foram produzidas. Das 11 localidades identificadas, apenas três estão fora do Brasil.

Figura 4 - Locais de apuração das matérias jornalísticas

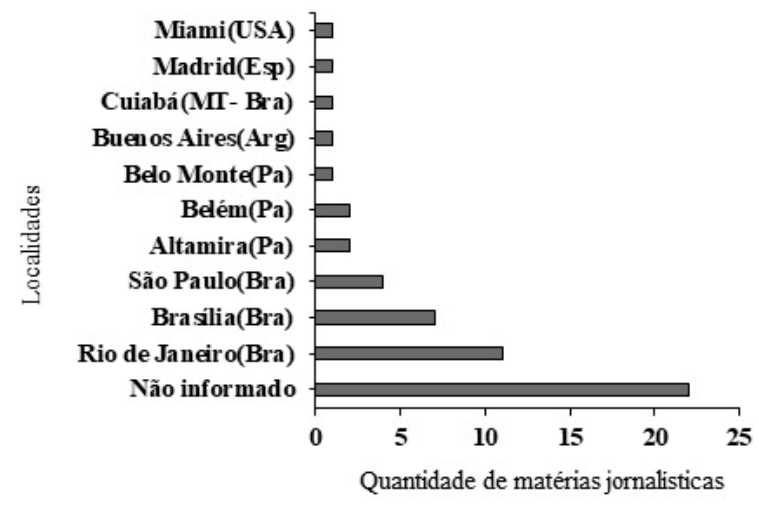

Fonte: pesquisa de campo, 2018.

Das matérias que não informaram a localidade (22), 88\% (19) são de veículos internacionais e 12\% (3) de nacionais. Foi no Rio de Janeiro a localidade de maior incidência de matérias produzidas (11), equivalente a 20\% dos conteúdos. Em seguida ficou Brasília, com sete matérias (13\%). Produziu-se uma matéria jornalística em Belo Monte, no Pará, pelo jornal The Guardian e duas em Altamira (PA), uma do The New York Times e outra da Folha de S.Paulo.

Seis jornais internacionais optaram por retratar do Brasil as matérias jornalísticas. The Guardian, com cinco matérias; seguido de El País, com quatro; El Mundo, três; Le Monde, duas; El Espectador e The New York Times, com uma cada. Apenas três matérias da Folha de S.Paulo não especificaram de qual parte do Brasil geraram o conteúdo.

Os jornais têm profissionais para noticiar os conflitos em torno da UHE Belo Monte, porém o fazem dos grandes centros urbanos. Tal comportamento pode gerar o distanciamento dos jornalistas em relação a fontes, nesse caso, os povos indígenas, que se encontram longe das cidades, ao passo que, gera a aproximação de fontes empresariais e do governo que, na maioria das vezes, estão nas grandes metrópoles. 
Há a presença de veículos de notícias estrangeiros com correspondentes no Brasil. Segundo Dalmolin e Silveira (2016, p. 2) "estes profissionais, ainda que morando no país, escrevem sobre a Amazônia sem ir à Amazônia. Tais profissionais residem principalmente na região Sudeste do Brasil, onde a chamada 'grande imprensa’ do país está sediada”.

Tudo isso contribui para que a Amazônia e os povos que nela habitam sejam retratados nos meios de comunicação como o que é observado nos filmes estrangeiros e nas histórias de europeus: cenários exóticos, belezas naturais, pobreza, isolamento.

Em seus estudos, Costa (2011) ressalta que a Amazônia e os povos que nela habitam, ao serem comparados à imagem civilizada e desenvolvida do Sul e Sudeste do Brasil ou dos países classificados de primeiro mundo, são retratados pela mídia como uma Amazônia de povos selvagens, sofridos anacrônicos, subalternos e atrasados, como mostra a Figura 5, a seguir.

Figura 5 - Imagem de notícia jornalística sobre os povos indígenas no Jornal The Guardian, de 22 de abril de 2016

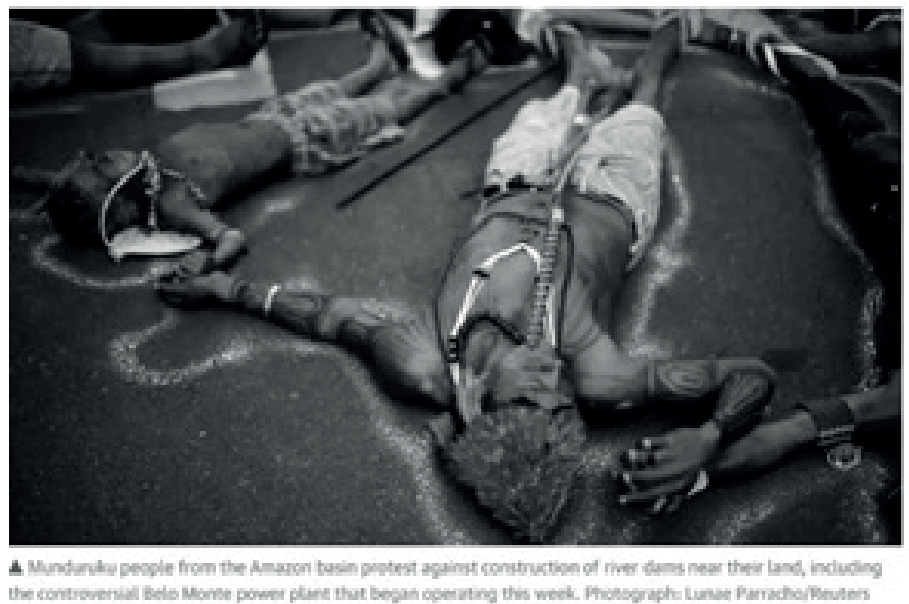

Fonte: https://www.theguardian.com/world/2016/apr/22/brazil-amazon-dam-project-suspended-indigenous-mundurukusao-luiz-do-tapajos. Acesso em: 9 set. 2018.

Essa imagem corrobora com as analisadas por Costa (2011), ao estudar os povos amazônicos, estereótipos, invisibilidade e a colonialidade. Por meio de imagens, Costa mostra que acontecimentos em torno da Amazônia, que envolvem os povos indígenas, parecem com filmes de ação, ao utilizar técnicas e posições de câmeras que geram um iminente confronto indígena.

\section{Fontes}

As Tabelas 1 e 2 apresentam as fontes e a quantidade de vezes que foram escutadas nas matérias jornalísticas. Identificou-se 13 fontes diferentes, classificadas em cinco 
categorias: oficial, alguém em função ou cargo público que se pronuncie pelo órgão mantido pelo Estado; empresarial, representantes das indústrias, comércio, serviços ou agronegócio; institucional, de organização sem fins lucrativos ou grupo social; notável, destacam-se pela fama; e especializada, trata-se de pessoa com conhecimento específico (cientista, perito) (SCHMITZ, 2011).

Tabela 1 - Fontes presentes nas matérias jornalísticas dos 15 jornais analisados

EL: El Espectador; EM: El Mundo; EP: El País; ET: El Tiempo; FSP - Folha de S.Paulo; JN: Jornal de Notícias; LN: La Nación; LF: Le Figaro; LeM: Le Monde; OG: O Globo; PD: People’s Daily; S.Z - Süddeutsche Zeitung; T.N.Y.T - The New York Times; T.S.T - The Sunday Times (Part. 1).

\begin{tabular}{l|cccccc} 
Fontes & EL & EM & EP & ET & FSP & JN \\
\hline Povos Indígenas & 2 & 5 & 2 & 1 & 9 & 0 \\
Movimentos Sociais & 3 & 6 & 6 & 0 & 6 & 0 \\
Governo & 3 & 3 & 4 & 0 & 3 & 0 \\
Poder Judiciário & 0 & 0 & 3 & 0 & 1 & 4 \\
Norte Energia & 0 & 0 & 4 & 0 & 0 & 0 \\
Cientistas & 0 & 2 & 0 & 0 & 1 & 0 \\
Eletronorte/Eletrobrás & 0 & 0 & 0 & 0 & 3 & 0 \\
Celebridades Americanas & 0 & 2 & 0 & 0 & 1 & 0 \\
Funai & 0 & 0 & 0 & 0 & 0 & 1 \\
Ribeirinhos & 1 & 0 & 0 & 0 & 0 & 0 \\
Segurança Pública & 0 & 0 & 0 & 0 & 2 & 0 \\
Imprensa Brasileira & 0 & 0 & 0 & 0 & 0 & 1 \\
Ibama & 0 & 0 & 0 & 0 & 0 & 0 \\
Total Individual & $\mathbf{9}$ & $\mathbf{1 8}$ & $\mathbf{1 9}$ & $\mathbf{1}$ & $\mathbf{2 4}$ & $\mathbf{6}$ \\
\hline
\end{tabular}

Fonte: pesquisa de campo, 2018.

Nota: Governo*: Ministério de Minas e Energia, Ministério do Meio Ambiente, Agência Nacional de Telecomunicações(Anatel), Dilma e Lula; Movimentos Sociais**: Ong’s, ativistas, sociedades civis organizadas, ambientalistas; Celebridades Americanas***: James Cameron e o cantor inglês Sting; Segurança Público****: Polícia Rodoviária Federal, Polícia Federal; Cientistas*****: pesquisadores, professores, especialistas; Poder Judiciário******: Tribunal de Justiça do Estado do Pará (TJE/Pa), Justiça Federal, Ministério Público Federal (MPF). 
Tabela 2 - Fontes presentes nas matérias jornalísticas dos 15 jornais analisados

EL: El Espectador; EM: El Mundo; EP: El País; ET: El Tiempo; FSP - Folha de S.Paulo; JN: Jornal de Notícias; LN: La Nación; LF: Le Figaro; LeM: Le Monde; OG: O Globo; PD: People’s Daily; S.Z - Süddeutsche Zeitung; T.N.Y.T - The New York Times; T.S.T - The Sunday Times (Part. 2).

\begin{tabular}{l|ccccccccc}
\hline Fontes & LN & LF & LM & OG & PD & S.Z & TG & T.N.Y.T & T.S.T \\
\hline Povos Indígenas & 0 & 1 & 3 & 0 & 1 & 3 & 8 & 2 & 0 \\
Movimentos Sociais & 1 & 0 & 3 & 0 & 0 & 0 & 7 & 4 & 0 \\
Governo & 0 & 0 & 2 & 1 & 1 & 2 & 5 & 3 & 0 \\
Poder Judiciário & 0 & 0 & 1 & 0 & 0 & 0 & 5 & 4 & 1 \\
Norte Energia & 0 & 0 & 2 & 2 & 0 & 1 & 3 & 1 & 0 \\
Cientistas & 0 & 1 & 0 & 0 & 0 & 0 & 2 & 0 & 0 \\
Eletronorte/Eletrobrás & 0 & 0 & 0 & 0 & 0 & 0 & 0 & 2 & 0 \\
Celebridades Americanas & 0 & 0 & 0 & 0 & 1 & 0 & 0 & 0 & 0 \\
Funai & 0 & 0 & 0 & 2 & 0 & 0 & 0 & 0 & 0 \\
Ribeirinhos & 0 & 0 & 0 & 0 & 0 & 0 & 2 & 0 & 0 \\
Segurança Pública & 0 & 0 & 0 & 0 & 0 & 0 & 0 & 1 & 0 \\
Imprensa Brasileira & 0 & 0 & 0 & 0 & 0 & 0 & 0 & 0 & 0 \\
Ibama & 0 & 0 & 0 & 0 & 0 & 0 & 1 & 0 & 0 \\
Total Individual & 1 & 2 & 11 & 5 & 3 & 6 & 33 & 17 & 1 \\
\hline
\end{tabular}

Fonte: pesquisa de campo, 2018.

Nota: Governo*: Ministério de Minas e Energia, Ministério do Meio Ambiente, Agência Nacional de Telecomunicações(Anatel), Dilma e Lula; Movimentos Sociais**: Ong’s, ativistas, sociedades civis organizadas, ambientalistas; Celebridades Americanas***: James Cameron e o cantor inglês Sting; Segurança Público****: Polícia Rodoviária Federal, Polícia Federal; Cientistas*****: pesquisadores, professores, especialistas; Poder Judiciário******: Tribunal de Justiça do Estado do Pará (TJE/Pa), Justiça Federal, Ministério Público Federal (MPF).

Os dados mostram que os movimentos sociais (36), povos indígenas (35), o governo (27), o poder judiciário (19) e a Norte Energia (13), na respectiva ordem, foram os cinco sujeitos mais escutados. Embora tenha um número maior da presença dos "Movimentos Sociais” e dos “povos indígenas”, todas enunciaram do mesmo lugar de fala. A começar pelo Governo, Poder Judiciário, Funai, Segurança Pública, Ibama, Norte Energia, Eletronorte/ Eletrobrás e Imprensa Brasileira. Todos compactuaram nas matérias com o mesmo discurso a favor da construção da usina.

A matéria de El Mundo, publicada em 26 de abril de 2010, tem como título "Lula garante que a futura hidrelétrica 'vai melhorar a qualidade de vida dos índios””. O conteúdo dedicou todos os 12 parágrafos para dar ênfase ao discurso de Lula para a construção da barragem, sendo um projeto modelo e de energia barata ${ }^{3}$.

3 Link da matéria do El Mundo https://www.elmundo.es/america/2010/04/26/brasil/1272289485.html. Acesso em: 9 set. 2018. 
Na Folha de S.Paulo, o título da matéria de 23 de março de 2011 informa: "Movimento social 'ameaça' empresas interessadas em Belo Monte. A notícia não apresenta nenhum documento ou mensagem do possível tom de ameaça e tem como fonte apenas representantes empresariais ${ }^{4}$.

Em pesquisa sobre a presença indígena na mídia, Corradi et al. (2017) ressaltam que a imprensa se estabelece a partir de relações de poder, que são historicamente construídas a partir dos fatos e discursos que forjam a identidades desses povos.

O jornal The Guardian e Folha de S.Paulo foram os que buscaram um número mais diversificado de personagens. Os jornais entrevistaram oito sujeitos diferentes. O Globo ouviu apenas fontes oficiais como o governo, a Norte Energia e a Fundação Nacional do Índio (Funai). Isso mostra que as fontes oficiais dominaram a produção da notícia em $\mathrm{O}$ Globo. Schmitz (2011) diz que as fontes oficiais são as preferidas da mídia, todavia, podem falsear informação para preservar os interesses e do grupo político.

Wolf (2003) enfatiza que quem dá o enquadramento à notícia é a fonte que fala na matéria jornalística. Ou seja, ao ouvir apenas fontes oficiais, o discurso jornalístico se torna apenas um único ponto de vista. Traquina (2001) ressalta que o jornalismo, por aceitar o que as fontes oficiais dizem, não altera o cenário que está sendo construído. Por seguindo, acabase por manter um mesmo ponto de vista.

O jornal do Reino Unido, The Sunday Times, e da Argentina, La Nación, usaram uma única fonte, respectivamente, os "Movimentos Sociais" e o "Ministério Público Federal (MPF)". O veículo que mais deu espaço nas matérias aos povos indígenas foi a Folha de S.Paulo, seguido do The Guardian.

Porém, esse espaço da Folha de S.Paulo é questionável, pois ocorreu de forma indireta e consequentemente silenciosa. Notou-se que a Folha reproduziu opiniões fragmentadas e expôs informações ditas pelos povos indígenas a partir de leituras de documentos, relatórios ou falas indiretas, conforme ilustrado na Figura 6, a seguir, pela notícia publicada em 4 de novembro de 2020, na Folha de S.Paulo.

4 Link da matéria https://folha.uol.com.br/mercado/2011/03/892930-movimento-social-ameaca-empresas-interessadas-em-belomonte.shtml?origin=folha. Acesso em: 9 set. 2018. 
Figura 6 - Imagem de notícia jornalística sobre os povos indígenas na Folha de S.Paulo

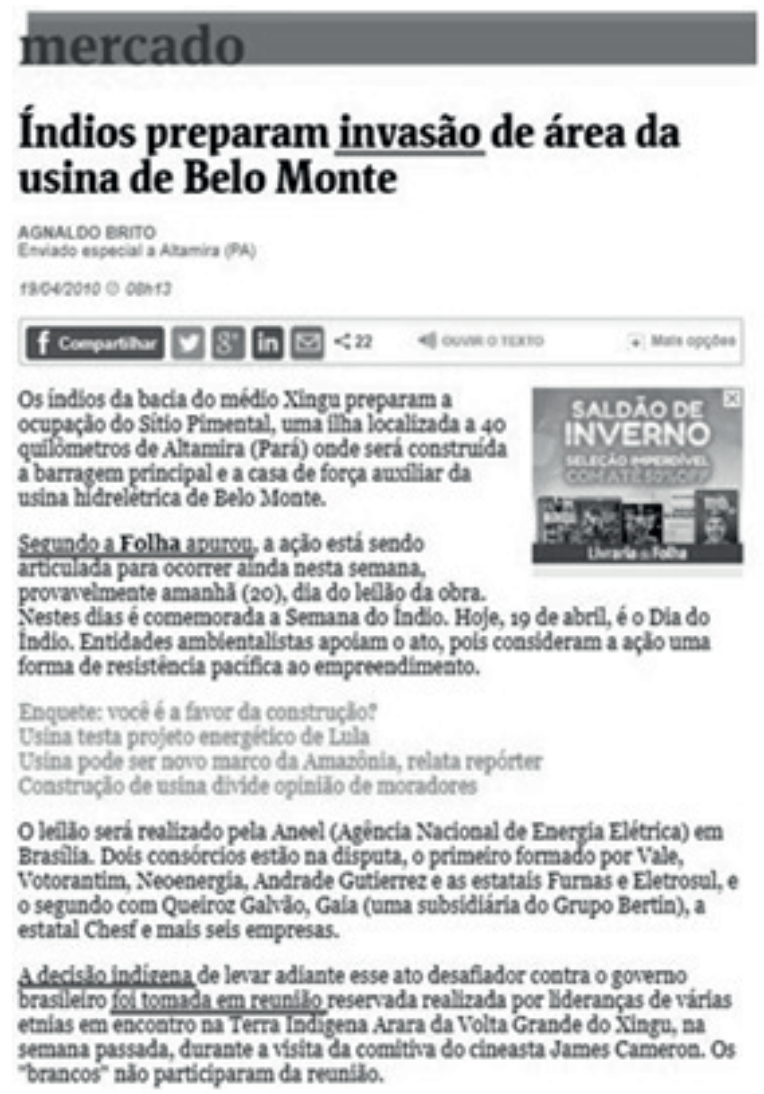

Fonte: https://www1.folha.uol.com.br/mercado/2010/04/722632-indios-preparam-invasao-de-area-da-usina-de-belomonte.shtml. Acesso em: 9 set. 2018.

A começar pelo título e a palavra “invasão”, utilizada para o ato de protesto. Tal termo passa a ideia de que os povos indígenas estão onde não deveriam estar, de que o espaço em que a Hidrelétrica passa a ser construída não é originalmente deles. Mesmo sentimento de séculos atrás, em que os colonizadores chegaram e se intitularam descobridores e exploradores de uma terra já povoada.

Esse pensamento corrobora com o de Guimarães (2018), que enfatiza que o termo “invasão” é manipular e inverter os papéis de quem de fato é o invasor. "lembrar das caravelas e dizer que esse é um conceito elaborado e implementado no contexto das invasões e conquistas territoriais europeias nas Américas. Esse conceito continua sendo manipulado através de representações indígenas” (GUIMARÃES, 2018, p. 61).

Identificá-los como responsáveis por um ato de invasão é uma das formas de representar o "índio como sendo o transtorno, o baderneiro, a sujeira, o estranho e o impuro da cidade. É aquele que sempre traz algum tipo de desordem, dúvida e incerteza aos que dominam e controlam o poder” (VIEIRA, 2015, p. 175). 
Com a frase "Segundo a Folha apurou”, não se identifica com quem realizou-se a apuração e de onde vieram as informações quanto as decisões dos povos indígenas. Não se cita a fala direta de nenhum indígena na matéria. Quanto a isso, Spivak (2010) diz que o discurso permanece na tática de neutralizar o outro, tornando-o subalterno - invisibilizado, tirando-lhe o direito de se autorrepresentar, relegando-o ao silêncio.

No trecho “A decisão indígena (...) foi tomada em reunião” exemplifica outra maneira de passar uma informação da fonte indígena, entretanto, sem expressá-la no texto de forma direta. O que garante ao leitor que, de fato, a informação foi apurada com algum representando dos povos indígenas?

A matéria chega até a lançar uma enquete para saber se as pessoas são a favor ou contra a construção da hidrelétrica, demonstrando assim, uma prática discursiva de interferência em decisões por parte da população ocidental sobre o futuro dos indígenas (NEVES, 2009).

Abaixo da enquete, há a chamada para outras duas matérias. Uma que vincula o nome de Lula aos testes da usina. Já a segunda notícia traz como expressão "novo marco na Amazônia” ao se referir à Usina, sendo então, algo inovador para a Amazônia.

A matéria encerra ao informar que a decisão indígena de "invadir” é um "ato desafiador contra o governo" e foi tomada durante uma reunião em que "brancos” não puderam participar. Percebe-se que a construção das relações entre governo, homens "brancos” e povos indígenas é nitidamente exposta como conflitantes e, portanto, pré-estabelecidas. Essa evidente relação hierarquizada de poder é notada por Corradi et al. (2017). Em seus estudos, é constada que a imprensa coloca os povos indígenas na posição de “reclamões" e não de povos que lutam para reafirmar os próprios direitos que não lhe são conferidos.

A falta de protagonismo dos povos indígenas revela-se como uma forma de violência física, verbal e submissão (ORLANDI, 1990). "Ao excluir-se os povos indígenas como fonte de informação, concede-se ao não índio e às instituições o poder de criar e dar sentido à construção discursiva (...) O que não é silenciado sobre o assunto é falado a partir das representações política, social e econômica do não índio” (FIGUEIREDO; MOURA, 2013, p. 79).

\section{Aspectos positivos e negativos}

Para identificar nas matérias a forma como os jornalistas apresentaram os impactos e os benefícios da UHE Belo Monte, elaborou-se as Tabelas 3 e 4, que mostram os “Aspectos Positivos e Negativos” referentes à construção da Usina, citados nos conteúdos. As matérias apontaram para 17 pontos negativos e sete positivos.

No montante de matérias analisadas, "Geração de Energia” e “Construção de Hospital, Casas e Escolas” foram os pontos positivos mais apontados. El País e El Mundo foram os dois jornais que mais destacaram os benefícios. Tanto a Folha de S.Paulo quanto o The Guardian, destacaram, respectivamente, duas e três vezes os pontos positivos da Usina.

Quanto aos aspectos negativos, o maior número apontado foi "Deslocamento populacional” (18), ao abordar a retirada da população indígenas das próprias moradias; 
“Inundações” (17), ao apresentar o alagamento causado pelo represamento do Rio Xingu; e "Desaparecimento de espécies dos rios” (8), ao mostrar a morte dos peixes e animais das florestas alagadas.

El Mundo frisou por 18 vezes aspectos negativos citados acima e outros além dos apresentados no parágrafo anterior. Posteriormente, El Mundo, The Guardian (18), El Espectador (16), El País (11) foram os que mais pontuaram aspectos negativos no texto.

A Folha de S.Paulo apresentou sete problemáticas advindas da construção da hidrelétrica no Xingu, por vezes, referindo-se como "Impacto Social” ou “Impacto Ambiental”. Essas duas categorias negativas apresentadas pela Folha não deixam claros quais impactos seriam causados pela hidrelétrica. Consequentemente, as problemáticas acabam por tornarse generalistas e sem foco em cima do problema, limitando-as nas possíveis discussões sobre o assunto. O Globo citou apenas um ponto negativo, o “deslocamento populacional”.

Os jornais El Tiempo, La Nación e Jornal de Notícias não informaram nenhum ponto positivo e negativo sobre a UHE Belo Monte. O Globo e People’s Daily não pontuaram nenhum quesito positivo. “Ausência de saneamento”, “Elevação da Temperatura”, “Desemprego” e "Mudanças no Xingu” foram únicos pontos negativos destacados pelo El Mundo, El País, Folha de S.Paulo e Le Figaro.

Como Costa (2018) já havia constatado, a cobertura feita pela imprensa sobre meio ambiente, de 1990 até a atualidade, não se caracteriza por matérias que mostrem as causas e consequências dos fenômenos. O mesmo autor chega à conclusão que coberturas assim causam mais desinformação do que informação aos cidadãos preocupados com a questão ambiental ou com políticas públicas relacionadas ao tema, principalmente na Amazônia.

As próprias matérias poderiam ser fontes de informação atualizada e contextualizada para os povos indígenas, porém deixam em falta. Bueno (2007) reforça que a essência do jornalismo ambiental, além de informativo e didático, é levar a temática do cuidado com a natureza e aqueles que a cercam. Todavia, a informação é afetada com a redução da interdisciplinaridade, vinculação das elites, exclusão dos segmentos sociais e a predominância de fontes oficiais governamentais.

Tabela 3 - Aspectos positivos da UHE Belo Monte apresentados nos jornais analisados

EE: El Espectador; EM: El Mundo; EP: El País; FSP: Folha de S.Paulo; LeF: Le Figaro; LeM: Le Monde; SZ: Süddeutsche Zeitung; TG: The Gardian; TNYT: The New York Times; TST: The Sunday Times (Part. 1).

\begin{tabular}{l|ccccc}
\hline Aspectos Positivos & EE & EM & EP & FSP & LeF \\
\hline Geração de Energia & 2 & 1 & 1 & 1 & 1 \\
Construção Hospital/ Casas/ Escola & 0 & 0 & 5 & 0 & 0 \\
Projeto Energético do Brasil & 1 & 1 & 0 & 0 & 0 \\
Emprego & 0 & 1 & 0 & 1 & 0 \\
Qualidade de Vida & 0 & 2 & 0 & 0 & 0 \\
Energia Barata & 0 & 1 & 0 & 0 & 0 \\
Preservação de Áreas Indígenas & 0 & 1 & 0 & 0 & 0 \\
Total Individual & $\mathbf{3}$ & $\mathbf{7}$ & $\mathbf{6}$ & $\mathbf{2}$ & $\mathbf{1}$ \\
\hline
\end{tabular}

Fonte: pesquisa de campo, 2018. 
Tabela 3.1 - Aspectos positivos da UHE Belo Monte apresentados nos jornais analisados

EE: El Espectador; EM: El Mundo; EP: El País; FSP: Folha de S.Paulo; LeF: Le Figaro; LeM: Le Monde; SZ: Süddeutsche Zeitung; TG: The Gardian; TNYT: The New York Times; TST: The Sunday Times (Part. 2).

\begin{tabular}{l|ccccc}
\hline Aspectos Positivos & LeM & SZ & TG & TNYT & TST \\
\hline Geração de Energia & 1 & 1 & 1 & 1 & 1 \\
Construção Hospital/ Casas/ Escola & 1 & 0 & 0 & 1 & 0 \\
Projeto Energético do Brasil & 0 & 0 & 2 & 0 & 0 \\
Emprego & 0 & 0 & 0 & 1 & 0 \\
Qualidade de Vida & 1 & 0 & 0 & 0 & 0 \\
Energia Barata & 0 & 0 & 0 & 0 & 0 \\
Preservação de Áreas Indígenas & 0 & 0 & 0 & 0 & 0 \\
Total Individual & $\mathbf{3}$ & $\mathbf{1}$ & $\mathbf{3}$ & $\mathbf{3}$ & $\mathbf{1}$ \\
\hline
\end{tabular}

Fonte: pesquisa de campo, 2018. (Nota: Construção*: casas, hospital, escolas).

Tabela 4 - Aspectos negativos da UHE Belo Monte apresentados nos jornais analisados

EE: El Espectador; EM: El Mundo; EP: El País; FSP: Folha de S.Paulo; LeF: Le Figaro; LeM: Le Monde; OG: O Globo; PD: People’s Daily; SZ: Süddeutsche Zeitung; TG: The Gardian; TNYT: The New York Times; TST: The Sunday Times (Part. 1).

\begin{tabular}{l|cccccc}
\hline Aspectos Negativos & EE & EM & EP & FSP & LeF & LeM \\
\hline Deslocamento* & 4 & 4 & 2 & 0 & 0 & 2 \\
Inundações & 4 & 3 & 4 & 2 & 0 & 1 \\
Desaparecimento de Espécies dos Rios & 0 & 1 & 0 & 2 & 0 & 0 \\
Desmatamento & 0 & 1 & 1 & 1 & 1 & 0 \\
Falta de Diálogo & 3 & 0 & 0 & 0 & 0 & 0 \\
Impactos Ambientais** & 2 & 2 & 0 & 1 & 0 & 0 \\
Assassinatos/ Violência & 0 & 3 & 1 & 0 & 0 & 0 \\
Impactos Sociais*** & 0 & 2 & 0 & 1 & 0 & 1 \\
Doenças & 0 & 0 & 1 & 0 & 0 & 0 \\
Inchaço Populacional & 0 & 0 & 1 & 0 & 0 & 0 \\
Abusos Trabalhistas & 2 & 0 & 0 & 0 & 0 & 0 \\
Costumes Sagrados & 1 & 1 & 0 & 0 & 0 & 0 \\
Transtornos Psicológicos & 0 & 0 & 1 & 0 & 0 & 0 \\
Ausência De Saneamento & 0 & 0 & 1 & 0 & 0 & 0 \\
Desemprego & 0 & 0 & 0 & 0 & 1 & 0 \\
Elevação Da Temperatura & 0 & 0 & 0 & 1 & 0 & 0 \\
Mudança no Xingu & 0 & 1 & 0 & 0 & 0 & 0 \\
Total Individual & $\mathbf{1 6}$ & $\mathbf{1 8}$ & $\mathbf{1 2}$ & $\mathbf{8}$ & $\mathbf{1}$ & $\mathbf{4}$ \\
\hline
\end{tabular}

Fonte: pesquisa de campo, 2018.

Nota: Deslocamento se trata das pessoas que foram remanejadas das residências devido as inundações/ Impactos Ambientais** e Impactos Sociais*** tratam-se dos problemas ambientais e sociais advindos da HE Belo Monte, mas sem especificá-los. Estas duas categorias tratam de forma genérica dos problemas). 
Tabela 4.1 - Aspectos negativos da UHE Belo Monte apresentados nos jornais analisados

EE: El Espectador; EM: El Mundo; EP: El País; FSP: Folha de São Paulo; LeF: Le Figaro; LeM: Le Monde; OG: O Globo; PD: People’s Daily; SZ: Süddeutsche Zeitung; TG: The Gardian; TNYT: The New York Times; TST: The Sunday Times (Part. 2).

\begin{tabular}{l|cccccc}
\hline Aspectos Negativos & OG & PD & SZ & TG & TNYT & TST \\
\hline Deslocamento* & 1 & 0 & 0 & 3 & 1 & 1 \\
Inundações & 0 & 1 & 2 & 0 & 0 & 0 \\
Desaparecimento de Espécies dos Rios & 0 & 0 & 1 & 2 & 2 & 0 \\
Desmatamento & 0 & 0 & 0 & 2 & 0 & 0 \\
Falta de Diálogo & 0 & 0 & 1 & 2 & 0 & 0 \\
Impactos Ambientais** & 0 & 0 & 0 & 1 & 0 & 0 \\
Assassinatos/ Violência & 0 & 0 & 0 & 1 & 0 & 0 \\
Impactos Sociais*** & 0 & 0 & 0 & 1 & 0 & 0 \\
Doenças & 0 & 0 & 0 & 2 & 0 & 0 \\
Inchaço Populacional & 0 & 0 & 0 & 2 & 0 & 0 \\
Abusos Trabalhistas & 0 & 0 & 0 & 0 & 0 & 0 \\
Costumes Sagrados & 0 & 0 & 0 & 0 & 0 & 0 \\
Transtornos Psicológicos & 0 & 0 & 0 & 1 & 0 & 0 \\
Ausência De Saneamento & 0 & 0 & 0 & 0 & 0 & 0 \\
Desemprego & 0 & 0 & 0 & 0 & 0 & 0 \\
Elevação Da Temperatura & 0 & 0 & 0 & 0 & 0 & 0 \\
Mudança no Xingu & 0 & 0 & 0 & 0 & 0 & 0 \\
Total Individual & $\mathbf{1}$ & $\mathbf{1}$ & $\mathbf{4}$ & $\mathbf{1 7}$ & $\mathbf{3}$ & $\mathbf{1}$ \\
\hline
\end{tabular}

Fonte: pesquisa de campo, 2018.

Nota: Deslocamento se trata das pessoas que foram remanejadas das residências devido as inundações/ Impactos Ambientais** e Impactos Sociais*** trata-se dos problemas ambientais e sociais advindos da HE Belo Monte, mas sem especificá-los. Estas duas categorias tratam de forma genérica dos problemas.

\section{Considerações Finais}

Constatou-se que os jornais mais influentes do mundo possuem uma visão ultrapassada e distorcida dos povos indígenas, a começar pela forma como são identificados como “índios”, "tribos", "invasores".

É notável que a imprensa nacional optou por invisibilizar os povos indígenas. Em alguns casos, nem pelo nome ou sobrenome são identificados, reflexo de gerações de invisibilidade. As fontes empresariais e oficiais ainda são tidas como detentoras da informação que prevalece. Embora os jornais nacionais - Folha de S.Paulo e O Globo - sejam os de maior circulação no Brasil e estejam mais próximos à UHE Belo Monte em relação aos outros países, isso não fez com que estivessem mais presentes em Belo Monte, com reportagens e matérias mais amplas. E, apesar de a maioria das matérias internacionais ter sido produzida no Brasil, isso não garantiu que os jornalistas estivessem no local dos fatos. 
A pesquisa também nos leva a refletir que a luta dos povos indígenas contra a UHE Belo Monte foi vista pelos jornais nacionais e internacionais a partir do viés político e econômico, reflexo de como a região amazônica é observada tanto fora quanto dentro do próprio país.

O The Guardian tentou, ainda que de forma tímida, possibilitar que os povos indígenas tivessem suas opiniões exposta aos públicos. Os demais sites estrangeiros ainda caminham para essa direção.

Embora os impactos da UHE Belo Monte tenham afetado diretamente as populações indígenas e a natureza, as matérias jornalísticas são, em quantidade inexpressiva, da editoria de Meio Ambiente, que deveria dar conta de um conteúdo mais explorado, embasado tecnicamente e compreendido por todos os perfis de público. Afinal, os impactos ambientais gerados na Amazônia refletem na região e fora dela.

Ainda há muito que se caminhar quanto ao jornalismo ambiental, nos grandes jornais de circulação no mundo, pelo menos como observou-se em notícias referentes à Usina Hidrelétrica de Belo Monte.

A pesquisa não só mostrou baixa representatividade desses povos em textos jornalísticos, mas o quanto a pauta socioambiental sofre influência política, econômica de um veículo, assim como, sofre influência de quem escreve, porque ainda há o olhar jornalístico colonizador predominante em representar esses povos. O jornalismo mudou, as formas de noticiar também, porém, os discursos colonizadores perpetuam-se por gerações entre brasileiros e estrangeiros.

Todo texto é produto de um sujeito carregado de saberes acumulados. Portanto, acredita-se que quem escreve deve se desconstruir de tudo aquilo que um dia aprendeu em livros didáticos ou filmes sobre os povos indígenas, para que então esses textos se efetivem e ganhem o sentido esperado.

\section{Referências}

AGUiAR, P. Agências de Notícias, Estado e Desenvolvimento: modelos adotados nos países BRICS. Brazilian Journalism Research, v. 12, n. 1, p. 34-59, 2016.

ALMEIDA. M. R. C. Os índios na História: abordagens interdisciplinares. Revista Tempo, v. 12, n. 23, 2007.

ALONSO, S. Belo Monte e a questão indígena. Novos Cadernos NAEA, v. 18, n. 2, p. 275-280, 2015.

ASSIS, F. O jornalismo além do lead: rotinas produtivas, anuências e condições para uma prática diferenciada. Revista Comunicação Midiática, v. 13, n. 3, p. 40-54. 2017.

ASSOCIAÇÃO NACIONAL DE JORNAIS (ANJ). Maiores jornais do Brasil. 2011.

AZEVEDO, F. A. Mídia e democracia no Brasil: relações entre o sistema de mídia e o sistema político. Opinião Pública, v. 12, n. 1, p.88-113, 2006.

BAPTISTA, M. L. C.; RODRIGUES, A.; LOPES, R. Estereótipos e amorosidade na aventura de Tainá: abordagem ecossistêmica comunicacional e a representação do indígena amazônico. Rizoma, v. 4, n. 1, p. 153-165, 2016. 
BARDIN, L. Análise de Conteúdo. S. Paulo: Edições 70, p. 225, 1977.

BENATTI, J. H. Internacionalização da Amazônia e a questão ambiental: o direito das populações tradicionais e indígenas à terra. Revista Amazônia Legal de estudos socio-jurídico-ambientais, Cuiabá, v. 1, n. 1, p. 23-39, 2007.

BERGER, C. Campos em confronto: a terra e o texto. Porto Alegre: UFRGS, 2003.

BERMANN, C. O projeto da Usina Hidrelétrica Belo Monte: a autocracia energética como paradigma. Novos Cadernos NAEA, v. 15, n. 1, p. 5-23, 2012.

BRASIL, Dilma inaugura usina hidrelétrica de Belo Monte, 2016 - Disponível em: http://www.brasil.gov.br/ governo/2016/05/dilma-inaugura-usina-hidreletrica-de-belo-monte. Acesso em: 28 abr. 2018.

BRASIL, FUNAI. UHE Belo Monte-Componente Indígena, Parecer técnico $\mathbf{n}^{0}$ 21. CMAM/CGPIMAFUNAI, Parecer Técnico n. 21-Análise do Componente Indígena dos Estudos de Impacto Ambiental. FUNAI, Brasília, DF, Brasil, 2009. 99 p. Disponível em: http://www.ibama.gov.br/licenciamento/index.php. Acesso em: 29 jan. 2018.

BRASIL, República Federativa. Diário da Câmara dos Deputados. Brasília. Congresso, 2005.

BRASIL. Ministério De Minas e Energia. Plano Nacional de Energia Elétrica 1987 / 2010. Plano 2010. Relatório Executivo. Rio de Janeiro, 1987. 100p. Disponível em: http://www.planalto.gov.br/ccivil_03/ decreto/1980-1989/anexo/and96652-88.pdf. Acesso em: 29 jan. 2018.

BRAZIL, ELETROBRÁS. Plano 2010: Relatório geral. Plano nacional de energia elétrica 1987/2010 (dezembro de 1987). Centrais Eletricas Brasileiras (ELETROBRAS), Rio de Janeiro, 1987.

BUENO, W. da C. Jornalismo Ambiental: explorando além do conceito. Desenvolvimento e Meio ambiente, n. 15, p. 33-44, 2007.

CAREGNATO, R. C. A.; MUTTI, R. Pesquisa qualitativa: análise de discurso versus análise de conteúdo. Texto \& Contexto-Enfermagem, v. 15, n. 4, p. 679-684, 2006.

CARNEIRO FILHO, A.; SOUZA, O. B. de. Atlas de pressões e ameaças às terras indígenas na Amazônia brasileira. São Paulo: Instituto Socioambiental, 2009, p. 47.

CHIZZOTTI, A. Pesquisa qualitativa em ciências humanas e sociais. 3. ed. Petrópolis: Vozes, 2010.

COELHO, P.; SILVA, M. T. da. O lucro social e financeiro do jornalismo de investigação. Media \& Jornalismo, v. 18, n. 32, p. 73-94, 2018.

COLLET, C.; PALADINO, M.; RUSSO, K. Quebrando preconceitos: subsídios para o ensino das culturas e histórias dos povos indígenas. Ed. 3, Rio de Janeiro: Contra Capa Livraria, 2014.

CORRADI, A.; ASSUMPÇÃO, D. J. F.; DOS SANTOS CORREIA, K. A Presença Indígena no Telejornal Liberal: Redes de Memória e Identidade. Latin American Journal of Studies in Culture and Society, v. 3, ed. especial, p. 1-21, 2017.

COSTA, L. M.; CUNHA, K. M.; SILVA, K. A. C. A utilização das fontes na construção da notícia: uma análise do discurso das revistas Veja e Carta Capital na construção da notícia. Revista Movendo Ideias. v. 16, n. 2, p. 18-26, 2011.

COSTA, V. M. T. À sombra da floresta: os sujeitos amazônicos entre o estereótipo, invisibilidade e colonialidade no telejornalismo da Rede Globo. 2011. 295 f. 2011. Tese de Doutorado. Tese (Doutorado em Comunicação) - Universidade Federal Fluminense, Rio de Janeiro.

DALMOLIN, A. R.; SILVEIRA, A. C. M. Um abismo vigiado: segurança e soberania no discurso jornalístico televisual sobre fronteiras na Amazônia. Revista Internacional de Ciencias Sociales, v. 5, n. 1, p. 29-41, 2016. 
DANNER, L. F.; DORRICO, J.; DANNER, F. A literatura indígena brasileira, o movimento indígena brasileiro e o regime militar: uma perspectiva desde Davi Kopenawa, Ailton Krenak, Kaká Werá e Alvaro Tukano. Espaço Ameríndio, v. 12, n. 2, p. 252-282, 2018.

DOURADO, M. F.; NÓBREGA, C. C.; BORTOLOTTO, F.; ALENCAR, A.; MOUTINHO, P. A gestão ambiental e territorial de Terras Indígenas da Amazônia brasileira: uma questão climática. Journal for Brazilian Studies, v. 5, n. 1, p. 230-253, 2017.

FAINGUELERNT, M. B. A trajetória histórica do processo de licenciamento ambiental da usina hidrelétrica de Belo Monte. Ambiente \& Sociedade, v. 19, n. 2, p. 247-266, 2016.

FEARNSIDE, P. M. Belo Monte: atores e argumentos na luta sobre a barragem amazônica mais controversa do brasil. Revista Nera, n. 42, p. 162-185, 2018.

FEARNSIDE, P. M. Hidrelétricas na Amazônia: impactos ambientais e sociais na tomada de decisões sobre grandes obras. Manaus: Editora do INPA, v. 1, 2015, p. 296.

FEIO, E. F. et al. Usina hidrelétrica e comunidades tradicionais: estudo de caso aplicado a UHE Belo Monte com base na demanda por energia elétrica e os conflitos socioambientais inerentes a este processo. Revista Científica do CESP/UEA, n. 5, p. 31-47, 2020.

FIGUEIREDO, V. de S.; MOURA, D. O. Silenciamento e ausências: a saúde dos povos indígenas na mídia impressa brasileira. Comunicologia - Revista de Comunicação da Universidade Católica de Brasília, v. 6, n. 2, p. 69-90, 2013.

FISHER, W. H. O contexto institucional da resistência indígena a megaprojetos amazônicos. In: OLIVEIRA, J. P. de; COHN, C. (Orgs.) Belo Monte e a questão indígena. ABA, Brasília-DF, 2014, p. 133-142.

FLEURY, L. C.; ALMEIDA, J A construção da Usina Hidrelétrica de Belo Monte: conflito ambiental e o dilema do desenvolvimento. Ambiente \& Sociedade, v. 16, n. 4, p. 141-158, 2013.

FRANCO, F. C. O.; FEITOSA, M. L. P. A. M. Desenvolvimento e direitos humanos. Marcas inconstitucionais no processo Belo Monte. Revista Direito IGV, v. 9, n. 1, p. 93-114, 2013.

GRUPIONI, L. D. B.; VIDAL, L. B.; FISCHMANN, R. Povos indígenas e tolerância: construindo práticas de respeito e solidariedade. São Paulo: EDUSP, 2001. p. 43-61. (Seminários 6; Ciência, Cientistas e Tolerância II).

GUIMARÃES, F. A. M. A temática indígena na escola: onde está o espelho? Revista Fórum Identidades, v. 3, p 57-65. 2008.

IBGE. Os indígenas no Censo Demográfico 2010. Primeiras considerações com base no quesito cor ou raça. Rio de Janeiro, 2012. Disponível em: https://ww2.ibge.gov.br/indigenas/indigena_censo2010.pdf. Acesso em: 28 out. 2013.

LEITE, R. L.; FARIAS, O. M. de. Estratégias enunciativas na produção do efeito de imparcialidade em notícias jornalísticas. Galáxia, n. 34, p. 175-185, 2017.

LIMA, M. E. O.; SANTOS, M. R. dos. A desumanização presente nos estereótipos de índios e ciganos. Psicologia: Teoria e Pesquisa, v. 32, n. 1, p. 219-228 2016.

LIMA, R. L. A; GADELHA, D. Colonialismo: recorrências e dispersões no discurso do audiovisual amazônico. Logos, v. 1, n. 22, p. 71-88, 2015.

LIMA-FILHO, M. F. Cidadania Patrimonial. Anthropológicas, v. 26, n. 2, p. 34-155, 2015.

LOUREIRO, J. J. P. Cultura amazônica: uma poética do imaginário. In: LOUREIRO, J. J. P. (Org.) Obras Reunidas. S. Paulo: Escrituras, 2002. 
MACHADO, M. M. A trajetória da destruição: índios e terras no Império do Brasil. 2006. 137 f. Dissertação (Mestrado em História Social) - Programa de Pós-Graduação em História Social, Universidade Federal Fluminense, Niterói, 2006.

MARQUES DE MELO, J. Gêneros jornalísticos: conhecimento brasileiro. In: MARQUES DE MELO, J. (Orgs.). Gêneros jornalísticos no Brasil. São Bernardo do Campo: Universidade Metodista de S. Paulo, 2010, p. 23-41.

MARQUES, M. As mudanças nas rotinas de produção das agências de notícias com a consolidação da internet no Brasil. 2005. 143 f. 2012. Dissertação (Mestrado em Comunicação) - Faculdade de Comunicação, Universidade de Brasília, Brasília, 2005.

MONTAÑO, M. Planejamento às avessas: os descompassos da avaliação de impactos sociais no Brasil. In: OLIVEIRA, J. P. de; COHN, C. (Orgs.). Belo Monte e a questão indígena. ABA, Brasília-DF, 2014 p. 33-49. MONTEIRO, J. M. O desafio da História indígena no Brasil. In: GRUPIONI, L. D. B.; SILVA, A. L. da Silva (Orgs.). A temática indígena na escola: novos subsídios para professores de 1 e 2 graus. Brasília: MEC:MARI:UNESCO, 1995.

MONTEIRO, J. M. O desafio da história indígena no Brasil. In: SILVA, A. L.; GRUPINI, L. D. B. (Org.). A temática indígena na escola: novos subsídios para professores de $1^{\circ}$ e $2^{\circ}$ graus. São Paulo/Brasília: Global/ MEC/UNESCO, 2000.

NEVES, I. A invenção do indio e as narrativas orais Tupi. 2009. 215 p. Tese (doutorado) - Universidade Estadual de Campinas, Instituto de Estudos da Linguagem, Campinas, SP.

NUNES, P. H. F. internacionalização da Amazônia: agentes e perspectivas. Textos\&debates, v. 1., n. 27, p. 161-176. 2015.

NUNES-FILHO, E. P. Modelo de desenvolvimento local na Amazônia Pré-Colonial: complexidade cultural e modernidade em sociedades pré-coloniais da Amazônia. Estação Científica, v. 1, n. 2, p. 99-109, 2011.

OLIVEIRA, J. P.; COHN, C. (Eds.). Belo Monte e a Questão Indígena. Associação Brasileira de Antropologia (ABA), Brasília, DF. 337 p. 2014.

OLIVEIRA, L.; MARQUES, Â. S. A imagem de organizações públicas e o sentido de público no discurso de charges sobre Belo Monte. Líbero, v. 15, n. 29, p. 59-70, 2012.

OLIVEIRA, N. Pinguelli defende necessidade de Belo Monte. REDE BRASIL ATUAL, 2010. Disponível em: https://www.redebrasilatual.com.br/ambiente/2010/04/pinguelli-defende-necessidade-de-belo-monte. Acesso em: 9 set. 2018.

ORLANDI, E. P. Terra à vista: discurso do confronto: velho e novo mundo. Cortez Editora, 1990.

PINTO, L. F. Amazônia em Questão: Belo Monte, Vale e outros temas. S. Paulo: B4 Editores, 2012. 307 p.

REGINATO, G.; BENETTI, M. As finalidades do jornalismo para os leitores: estudo da audiência dos jornais Folha, Globo e Estadão. In: ASSOCIAÇÃO NACIONAL DE PROGRAMAS DE PÓS-GRADUAÇÃO EM COMUNICAÇÃO. ENCONTRO ANUAL (COMPÓS), 26, 2017, S. Paulo: Faculdade Cásper Líbero, 2017. Anais....

RICARDO, F. et al. Impactos da PEC 215/2000 sobre os Povos Indígenas, Populações Tradicionais e o Meio Ambiente. Instituto Socioambiental, 2015. Disponível em: https://www.socioambiental.org/sites/blog. socioambiental.org/files/nsa/arquivos/isa_relatoriopec215-set2015.pdf. Acesso em: 23 abr. 2017.

SANTOS, T.; SANTOS, L.; ALBUQUERQUE, R.; CORREAA, E. Belo Monte: Impactos sociais, ambientais, econômicos e políticos. Tendências, v. 13, n. 2, p. 214-227, 2012. 
SCHMITZ, A. A. Fontes de notícias: ações e estratégias das fontes no jornalismo. Florianópolis: Combook, 2011.

SCHWARTZMAN, S. et al. The natural and social history of the indigenous lands and protected areas corridor of the Xingu River basin. Phil. Trans. R. Soc. B, v. 368, n. 1619, p. 1-12, 2013.

SELIGMAN, L.; FURTADO, M. L. Interação online: o jornalismo que provoca a reação dos leitores na web. Estudos em Comunicação, v. 9, p. 391-409, 2011.

SILVA, C. R.; GOBBI, B.; SIMÃO, A. A. O uso da Análise de Conteúdo como uma ferramenta para a pesquisa qualitativa: descrição e aplicação do método. Organizações Rurais \& Agroindustriais, v. 7, n. 1, p. 70-81, 2005.

SPIVAK, G. C. Pode o subalterno falar? Belo Horizonte: Editora UFMG, 2010. p. 23-98.

STARKMAN, Dn. The Watchdog that didn't bark, the financial crises and the disappearance of investigative journalism. New York: Columbia University Press, 2014.

STROPPER, M. T. D. Inflexão Das Ongs Ambientalistas Após 1990: Um estudo sobre a atuação das ONGs no caso da Usina Hidrelétrica de Belo Monte. 2014. 211 p. Tese (Doutorado em Geografia) - Instituto de Geociências, Universidade Federal do Rio Grande do Sul. RS, 2014.

SUDATTI, A. B. Direitos humanos e luta por justiça ambiental: o caso de Belo Monte. Cadernos de Direito, v. 14, n. 26, p. 147-166, 2014.

TAVARES, J. Formação como construção do conhecimento científico e pedagógico. In: SÁ CHAVES, Idália (Org.). Percursos de formação e desenvolvimento profissional. Porto: Porto Editora, 1997, pp. 59-73.

TEIXEIRA, T. G. Jornalismo ambiental: o desafio da construção da notícia soft news. Vozes e Diálogo, v. 13, n. 2, p. 73-85, 2014.

TRAQUINA, N. O estudo do jornalismo no século XX. São Leopoldo. Unisinos, 2001.

VIEIRA, C. M. N. O que dizem as crianças não indígenas sobre as populações indígenas: um estudo a partir de desenhos infantis. Tellus, n. 28, p. 167-176, 2015.

VERDUM, R. As obras de infraestrutura do PAC e os povos indígenas na Amazônia brasileira. Brasília: INESC, 2012.

WOLF, M. Teorias das comunicações de massa. São Paulo: Martins Fontes, 2003.

ZAGO, G. da S.; BASTOS, M. T. Visibilidade de Notícias no Twitter e no Facebook: Análise Comparativa das Notícias mais repercutidas na Europa e nas Américas. Brazilian Journalism Research (Online), v. 9, p. 116-133, 2013.

\section{Renata da Cruz Paes}

Jornalista, mestra em Ciências Ambientais pela Universidade do Estado do Pará (UEPA). Já atuou como assessora de imprensa da UEPA. Tem matérias jornalísticas publicadas em revistas e jornais de Belém (PA) com temáticas voltadas ao meio ambiente e ciência. E-mail: contact.renatapaes@ gmail.com. 


\section{Priscila Sanjuan de Medeiros Sarmento}

Doutora em Ciências Ambientais pela Universidade Federal do Pará (UFPA). Apresenta experiência em ecologia e ecologia humana. Já foi bolsista do Programa Nacional de Pós-Doutorado (PNPD) no programa de Pós-Graduação em Ciências Ambientais da Universidade do Estado do Pará (20172018). No Pós-Doutorado Empresarial no Instituto Tecnológico Vale/Desenvolvimento Sustentável (Belém-PA), durante o ano de 2019, desenvolveu estudos no âmbito da recuperação de áreas degradadas pós mineração. Atualmente é pesquisadora colaboradora em projetos desenvolvidos por pesquisadores do Museu Paraense Emílio Goeldi, da Universidade do Estado do Pará e do Instituto Tecnológico Vale/Desenvolvimento Sustentável. E-mail: priscilasanjuanbio@yahoo.com.br.

\section{Altem Nascimento Pontes}

Doutor em Ciências, na modalidade Física, pela Universidade Estadual de Campinas. Atualmente é coordenador do Programa de Pós-Graduação em Ciências Ambientais da Universidade do estado do Pará (Uepa). É professor associado II da Universidade Federal do Pará e Professor Adjunto IV da Universidade do Estado do Pará. Sua linha de pesquisa é Estudos e Pesquisas Interdisciplinares que envolvam Ciência, Tecnologia, Inovação, Educação, Cultura, Saúde e/ou Meio Ambiente. Outra linha de pesquisa de interesse é a Modelagem Ambiental e Ecológica de Ecossistemas Amazônicos. E-mail: altempontes@hotmail.com.

Recebido em: 21.03.2019

Aprovado em: 09.09.2020

Este artigo é publicado em acesso aberto (Open Access) sob a licença Creative Commons Attribution Non-Commercial (CC-BY-NC), que permite uso, distribuição e reprodução em qualquer meio, sem restrições, desde que sem fins comerciais e que o trabalho original seja corretamente citado. 